\title{
Duplicated pyelocaliceal system with partial duplication of ureter
}

\author{
Musharraf Husain, Firdous Hajini, Ashraf Bhatt
}

Department of General

Surgery, HIMSR,

Jamia Hamdard, New Delhi, Delhi, India

\section{Correspondence to}

Dr Musharraf Husain, drmhusain1@gmail.com
To cite: Husain M, Hajini $F$ Bhatt A. BMJ Case Rep Published online: [please include Day Month Year] doi:10.1136/bcr-2013-

009115

\section{DESCRIPTION}

Duplicated ureter is a congenital condition in which the ureteric bud, the embryological origin of the ureter, splits resulting in two ureters draining a single kidney (figure 1). It is the most common renal abnormality, occurring in approximately 1\% of the population. ${ }^{12}$ Duplicated ureter is more common in women. Ureteral duplication is either partial, that is, the two ureters drain into the bladder via a single common ureter or complete in which two ureters drain separately. It can be asso-

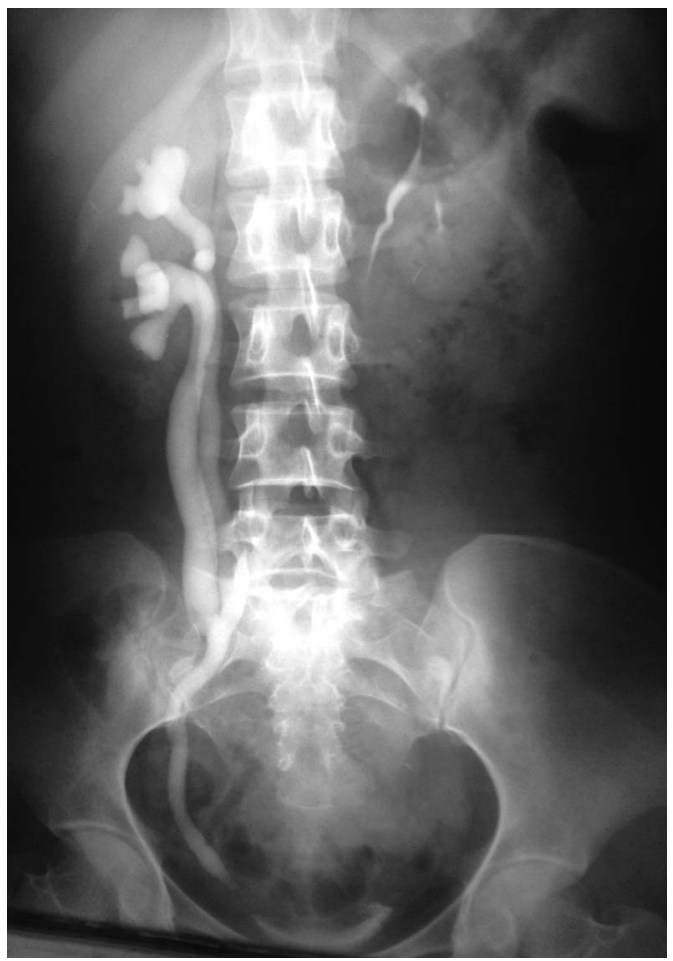

Figure 1 Intravenous urography showing left sided hydronephrotic duplex pyelocaliceal system with partial duplication of the ureter. ciated with a variety of congenital genitourinary abnormalities. They are usually asymptomatic and detected incidentally on imaging studies. Excretory urographic findings are almost always diagnostic. Double ureter and duplex system have potential for future complications, such as the collecting system obstruction, lithiasis, ureterocele and vesicoureteral reflux. ${ }^{3}$ The early detection of the anomalies are helpful in avoiding complications related to the duplex collecting system.

\section{Learning points}

- Developmental anomalies of the kidney, ureter and urinary bladder can lead to complications which are preventable.

- Early detection of the anomalies can avoid complications related to the duplex collecting system.

Acknowledgements Dr Abdul Hai, Assistant Professor, HIMSR, Jamia Hamdard, New Delhi.

Contributors $\mathrm{MH}$ was responsible for the conception, design, drafting of the article. FH was responsible for the acquisition of data. $A B$ helped in revising and drafting the article.

Competing interests None.

Patient consent Obtained.

Provenance and peer review Not commissioned; externally pee reviewed.

\section{REFERENCES}

1 Siomou $E$, et al. Duplex collecting system diagnosed during the first 6 years of life after a first urinary tract infection: a study of 63 children. J Urol 2006;175:678-81; discussion 681-2.

2 Gatti J, Murphy J, Williams J, et al. Emedicine overview. Ureteral duplication, ureteral ectopia, and ureterocele. http://emedicine. medscape.com/article/1017202-overview (accessed 8 April 2013).

3 Prakash, et al. Double ureter and duplex system. Urol 2011;8:145-8.

Copyright 2013 BMJ Publishing Group. All rights reserved. For permission to reuse any of this content visit http://group.bmi.com/group/rights-licensing/permissions.

BMJ Case Report Fellows may re-use this article for personal use and teaching without any further permission.

Become a Fellow of BMJ Case Reports today and you can:

- Submit as many cases as you like

- Enjoy fast sympathetic peer review and rapid publication of accepted articles

- Access all the published articles

- Re-use any of the published material for personal use and teaching without further permission

For information on Institutional Fellowships contact consortiasales@bmjgroup.com

Visit casereports.bmj.com for more articles like this and to become a Fellow 